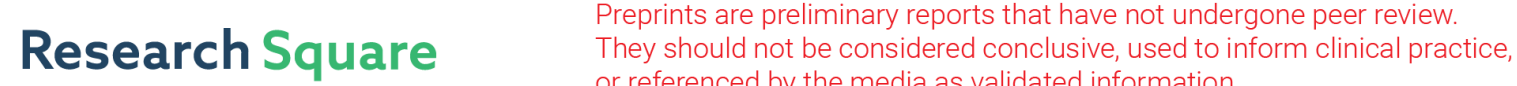 or referenced by the media as validated information. \\ Phenological Traits, Litterfall Production, and Carbon Sequestration Rates of Major Three Species in the Sundarbans
}

Md. Kamruzzaman ( $\sim$ mkzamanku@gmail.com )

Kyoto Daigaku

Sumonta Kumar Paul

Khulna University

\section{Research}

Keywords: Vegetative phenology, Reproductive phenology, Aboveground carbon, Belowground carbon, Annual litterfall

Posted Date: October 29th, 2020

DOl: https://doi.org/10.21203/rs.3.rs-97339/v1

License: (c) (i) This work is licensed under a Creative Commons Attribution 4.0 International License.

Read Full License 


\title{
Phenological traits, litterfall production, and carbon sequestration rates of major three species in the Sundarbans
}

\author{
Md. Kamruzzaman ${ }^{\text {a }}$, Sumonta Kumar Paul ${ }^{\mathrm{a}, \mathrm{b}}$
}

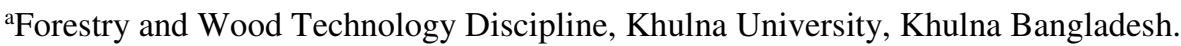

baboratory of Forest Utilization, Faculty of Agriculture, Kyoto University, Kyoto, Japan.

${ }^{\$}$ Contact: mkzamanku@gmail.com

Keywords: (maximum 5)

Vegetative phenology; Reproductive phenology; Aboveground carbon; Belowground carbon; Annual litterfall 


\section{Abstract \\ Background}

Attempt to compare the phonological pattern of the three mangrove species: Heritiera fomes, Bruguiera sexangula, and Xylocapus mekongensis in the Sundarbans mangrove forest by observing the litterfall data over 3 years.

\section{Results}

All these three species showed highest litterfall of leaves and stipules in summer and lowest in winter. In case of B. sexangula, it also showed its second peak of leaves litterfall in the rainy season. Branch litterfall for the three species was occurred all over the year without having a distinct seasonal pattern. Flowering was observed in February - June and March - May for H. fomes and X. mekomgensis, respectively. Fruiting was observed for $H$. fomes and X. mekongensis in between the month of March - May and April - June respectively. Peak of mature fruit or seed litterfall was observed in July and August for both H. fomes and X. mekongensis respectively. Litterfall of flower buds, flowers and propagule for B. sexangula was observed throughout the year and peak flower buds, flowers, and propagule litterfall was found in the month of January, March, and July respectively. Kendall's coefficient of concordance showed that all the organs of litterfall were concordant during the study period. Autocorrelation coefficient revealed that all the parts of litterfall followed a clear annual cycle except branches. Mean total litterfall was calculated $1014.6 \pm 12.7 \mathrm{~g} \mathrm{~m}^{-2}$ year $^{-1}$ for $H$. fomes, $1047.3 \pm 21.3 \mathrm{~g} \mathrm{~m}^{-2}$ year $^{-1}$ for $X$. mekongensis and $1640.2 \pm 14.1 \mathrm{~g} \mathrm{~m}^{-2}$ year ${ }^{-1}$ for $B$. sexangula of which leaves litterfall contributed more than $50 \%$ of total litterfall for all the three species. H. fomes, B. sexangula and X. mekongensis none of them exhibit any correlation between stipules litterfall and reproductive organs litterfall.

\section{Conclusion}

The findings may contribute to an understanding of vegetative and reproductive phenology, litterfall production, and carbon sequestration rate of the major mangrove species in Sundarbans mangrove forests, and also its role in global $\mathrm{C}$ budgets. 


\section{Background}

Mangrove forests are among the world's most productive ecosystems, as well as unique wetland ecosystems in intertidal coastal regions of the tropics and subtropics (Lugo and Snedaker 1975; Nagarajan et al. 2008). It is also an important contributor of nutrients to coastal ecosystems. Their litter fall is a valuable indicator of their productivity and input of materials and energy into sub tidal systems (Mackey and Smail 1995). Litterfall also indicates phenological events for mangrove species (Leach and Burgin 1985; Duke 1990; Clark 1994) when the time lag between the formation and shedding of plant organs is known (Mehlig 2006). Mangrove phenology is important for understanding both the contribution of mangroves to near-shore productivity and plant-animal interactions within the community itself (Coupland et al. 2005). Many studies have documented mangrove litterfall to assess mangrove productivity; and fewer studies have documented mangrove phenology, particularly reproductive phenology (Kamruzzaman et al. 2013). Biomass and net primary productivity of mangrove forest have been studied previously in different mangrove forest across the world (e.g., Saintilan, 1997; Komiyama et al., 2000; Kamruzzaman et al. 2017) and the purpose of biomass estimation and productivity of mangrove forest are mainly in terms of ecosystem management and evaluating carbon stock (Tamai et al., 1986; Komiyama et al., 2000). Patterns of carbon accumulation and its relationship to species dominance (richness) and individual tree size will be determined by the age and size distribution of trees in stands and of history of stand development in the area.

This study was conducted in a mangrove community within the oligohaline zone of the Sundarbans, Bangladesh. There are numerous studies on litterfall production in mangroves, especially in tropical and subtropical regions of Australia (Bunt 1982; Mackey and Smail 1995), Thailand (Christensen 1978; Angsupanich and Aksornkoae 1994), Malaysia (Ashton et al. 1999), and Okinawa Island, Japan (Kamruzzaman et al. 2012), and there have been no previous studies, which examined phenology, litterfall production and carbon sequestration rate of the major 
mangrove communities in this area. Very few previous studies examined allometry, biomass, and carbon storage of the Sundarbans Reserve Forest (SRF), Bangladesh with respect to its biodiversity and role in carbon sink among the other forest ecosystems in the tropics (Iftekhar and Saenger 2008, Rahman et al. 2015, Hossain et al. 2015), and there also have been no previous studies which examined carbon sequestration rate among the major species of the mangrove communities in this area. The aims of the present study were to investigate the vegetative and reproductive phenology of three major mangrove species growing in Sundarbans, determine the development period of each reproductive organ, to determine the rate of successful conversion from flowers to propagules for all the three species, and to compare the biomass estimation including above and below ground biomass, its incremental rate, carbon storage, and carbon sequestration rate among the mangrove successional stages at different locations of the Sundarbans.

\section{Materials and Methods}

\section{Litterfall collection}

Litterfall will be collected using 1-mm mesh litter traps with mouth areas of $0.2 \mathrm{~m}^{2}$. Two litter traps will be placed in each plot $>1 \mathrm{~m}$ high from the ground to avoid tidal water. The litter traps will be emptied monthly; the collected litterfall will keep in a cotton bag and carried to the laboratory where it will be separated into leaves, stipules, branches, flower buds, flowers, and propagules. Individual components of the litterfall will be dried at $80^{\circ} \mathrm{C}$ for $48 \mathrm{~h}$, desiccated at room temperature, and then weighed using a digital balance. Litterfall was collected using 1-mm mesh litter traps with a mouth area of $0.2 \mathrm{~m}^{2}$. Two litter traps were placed at $1 \mathrm{~m}$ above the ground in each plot to avoid tidal water. Litterfall was collected monthly in a cotton bag and separated in the laboratory into leaves, stipules, branches, flower bud primordia, flower buds, flowers, fruits, and propagules. These separated components of the litter were dried at $80^{\circ} \mathrm{C}$ for 
$48 \mathrm{~h}$, desiccated at room temperature, and then weighed using a digital balance. Reproductive parts (i.e., flowers, fruits, and propagules) were counted to estimate successful fruits and propagules.

\section{Biomass production and increment measurement}

Although allometric relationships have been developed between $D B H$ and weight for a number of mangrove species around the world, biomass production depends on the interaction between edaphic, climatic and topographic factors of the specified area and the species that occurred on the specific area. Unfortunately there is no developed allometric equation for biomass estimation of the studied mangrove species encountered in this study. So we tentatively apply the following aboveground biomass equation for all the mangrove tree species (Chave et al. 2005).

$$
A G B=\rho \times \exp \left(-1.349+1.980 \ln (D)+0.207(\ln (D))^{2}-0.0281(\ln (D))^{3}\right)
$$

where $\mathrm{AGB}=$ aboveground biomass, $\rho=$ wood density, $\mathrm{D}=\mathrm{DBH}$. The wood density data were obtained from Global Wood Density Database (Chave et al. 2009).

Below-ground biomass of mangrove tree species was estimated using a common allometric relationships between dbh and biomass, established by Komiyama et al. (2005).

$$
B G B=\left(0.199 \quad \rho^{0.899} D^{2.22}\right)
$$

where $\mathrm{BGB}=$ belowground biomass, $\rho=\operatorname{wood}$ density, $\mathrm{D}=\mathrm{DBH}$. Individual tree's biomass calculation for each species was estimated using the same allometric equation. The common allometric relationship for root weight was derived from the relationship between below-ground and above-ground weight of trees, so wood density is same for both above-ground and below-ground weight estimation.

\section{Carbon estimation and sequestration measurement:}

Conversion of biomass of tress to carbon mass was done by multiplying forest biomass by 0.5 as carbon concentration is regularly 50\% (Gifford 2000). Carbon sequestration is defined as the rate of carbon change in stored carbon with time. In this study, the estimation of stored carbon in the above 
and below ground of the selected mangrove trees have been made from March 2018 to February 2020 in the same locations. Hence, the rate of change in stored carbon in the marked species (carbon sequestration) was calculated by dividing the difference in stored carbon through the denoted time (in this case 2 years).

\section{Statistical analyses}

Kendall's coefficient of concordance $W$ was used to evaluate a degree of the similarity in the monthly change among years for each litterfall component. When $W=1.0$, the monthly changes of the litterfall are concordant among years, while when $W=0.0$, the monthly changes are completely different among years. $\chi^{2}(=(n-1) \cdot k \cdot W)$ test with $n-1$ degrees of freedom was used to determine the significance of the $W$ value. The autocorrelation coefficient $\left(r_{\mathrm{k}}\right)$ was calculated for each litterfall component to evaluate its yearly cycle: $r_{k}=\frac{\sum_{j=1}^{N-k}\left(X_{j}-\bar{X}_{1, N-k}\right)\left(X_{j+k}-\bar{X}_{1+k, N}\right)}{\sqrt{\sum_{j=1}^{N-k}\left(X_{j}-\bar{X}_{1, N-k}\right)^{2} \sum_{j=1}^{N-k}\left(X_{j+k}-\bar{X}_{1+k, N}\right)^{2}}}$, where $k(=0,1,2, \ldots)$ is the time lag in months; $N(=48)$ is the total number of months in the time series; $X_{j}$ and $X_{j+k}$ are litterfall components of the $j^{\text {th }}$ month and $(j+k)^{\text {th }}$ month, respectively; and $\bar{X}_{1, N-k}$ and $\bar{X}_{1+k, N}$ are the mean values of the components from the first to the $(N-k)^{\text {th }}$ month and from the $(1+k)^{\text {th }}$ to the $N^{\text {th }}$ month, respectively.

A one-way ANOVA was run to test significance differences in the numbers of flowers, fruits, and propagules, and in the annual masses of litterfall components among the species. Bonferroni's multiple comparison was used for post-hoc-tests using SPSS software (ver. 11.5, SPSS Inc., New York, USA).

\section{Results}

\section{Vegetative and Reproductive Phenology}

All three species showed a similar pattern in the seasonality of leaf litterfall (Fig. 1a). Leaf litterfall of B. sexangula was greatest in spring and summer (March-July) and lowest in winter 
(December). Xylocarpus mekongensis showed a distinct unimodal leaf litterfall pattern, with a peak in February i.e. in the winter and beginning of spring and lowest in rest of the months. Heritiera fomes also showed a unimodal leaf litterfall pattern, with a peak in March. Stipule litterfall, an indicator of leaf emergence, and the new leaf emergence of $B$. sexangula was highest in July i.e. in summer and was lowest in December i.e., in winter. Stipule litterfall of $H$. fomes was also highest in April-May i.e., in summer and lowest in winter (December-January). Similarly, X. mekongensis showed a distinct monthly pattern of new leaf emergence, with a peak in March (spring) and was lowest in winter. Kendall's coefficient of concordance, $W$, revealed that the monthly trends in leaf and stipule litterfalls for the three species showed strong and significant concordance among the study years (Table 1). However, branch litterfall did not show any clear monthly trend in B. sexangula and $H$. fomes, but had clear monthly pattern of $X$. mekongensis.

Flower buds were very difficult to separate from other litterfall components for $H$. fomes and X. mekongensis, because of its small size. Therefore, I am unable to detect any seasonal pattern in litterfall of flower bud of $H$. fomes and X. mekongensis, but in case of litterfall of flower buds from B. sexangula was fluctuated throughout the year, with highest in summer season and lowest in winter (Fig. 8a). Kendall's $W$ values revealed that litterfall flower buds of B. sexangula showed significant concordance among years (Table 1).

Flowers from B. sexangula were found in most months of the year, with a maximum in March and a minimum in December (Fig. 2b). Flower Litterfall of $H$. fomes was observed from February through June, with the highest abundance in March. Litterfall of $X$. mekongensis flowers were also observed from March to May, with a peak in April. No H. fomes and X. mekongensis flowers were observed from July to January and June to January, respectively. Generally, unfertilized flowers were aborted and fell from trees within a few days, and some pollinated flowers also fell. Kendall's coefficient of concordance W values revealed that monthly 
trends of flower litterfall for all three species did not show any significant concordance among years (Table 1).

Bruguiera sexangula has no apparent fruit stage because propagule development immediately follows fertilization, with a single hypocotyl emerging from an attached mature calyx and matured into propagules. Immature fruits of $H$. fomes were found from March to May, with a massive production of immature fruits were in May i.e., just after one month of flower production and in summer season with dry climatic condition. Litterfall of immature fruits of $X$. mekongensis was observed from April to June that is also summer season.

Over time, immature fruits of $H$. fomes and $X$. mekongensis turned into matured fruits. Bruguiera sexangula propagules were found throughout the year, but abundance of mature propagules was highest in July and August while propagules found in October to June was immature. Mature fruits of $H$. fomes and X. mekongensis dropped between July and August. Kendall's coefficient of concordance $W$ values revealed that monthly trends of mature fruit litterfall for $H$. fomes and $X$. mekongensis species strong and significant concordance among years (Table 1).

Monthly trend of vegetative, reproductive, as well as total litterfall showed a species specific a unimodal pattern. Kendall's W values showed that seasonal trends in vegetative and total litterfall of all the three species showed strong and significant concordance among years (Table 1)

As shown in Table 2, the mean numbers of flowers produced did not differ significantly between $B$. sexangula and $X$. mekongensis, but there was a significant difference in the number of flowers between these two species and H. fomes. Mature or propagule number differed significantly between $H$. fomes and other two species. The mean conversion percentage of flowers to mature fruits or propagules ( \pm SE) was $3.9 \pm 0.2 \%$ for $B$. sexangula, $6.4 \pm 0.3 \%$ for $H$. 
fomes, and $5.0 \pm 0.3 \%$ for $X$. mekongensis. Flower and propoagule number of $H$. fomes differed significantly with the other two species (Table 2).

Young, tender, green, and yellow or senescence leaves contributed the most to total litterfall. Mean leaf litterfall ( \pm SE) of B. sexangula, H. fomes, and X. mekongensis was $866.9 \pm$ $124.8,533.6 \pm 81.6$, and $681.9 \pm 119.3 \mathrm{~g} \mathrm{~m}^{-2}$ year $^{-1}$, respectively, which represent $52.9,52.6$, and $50.4 \%$ of the total litterfall for each species, respectively (Table 3). Mean propagule litterfall ( \pm SE) of B. sexangula, H. fomes, and X. mekongensis was $219.0 \pm 106.9,141.9 \pm 51.9$, and 45.8 $\pm 5.8 \mathrm{~g} \mathrm{~m}^{-2}$ year $^{-1}$, respectively, which contributed $13.4,14.0$, and $4.4 \%$ to the total litterfall, respectively. There was no significant difference in vegetative organ litterfall component among the studied species, but the reproductive organ litterfall of $B$. sexangula was significantly different from other two species (Table 3).

The autocorrelation coefficient revealed that leaf litterfall and stipule litterfall (Fig. 4a and Fig. 4b) of three species demonstrated a clear annual cycle for each of the component. Litterfall of branches (Fig. 4c) of all three species did not show any clear cycle. Litterfall of flower buds of B. sexangula, flowers, fruits and propagules of all three species showed a clear annual cycle (Fig 5a, 5b, and 5c).

\section{Carbon sequestration}

The rate of carbon sequestration varied between mangrove species and site of the stand. A. officinlis showed highest, whereas, A. cucullata presented the lowest rate of carbon sequestration rate (Fig. 6), additionally, AGB, BGB and Total Biomass (TB) was higher in Karamjol forest area, this area also accumulated significant and highest amount of carbon (Fig. 8) followed other areas, this could be happened due to higher density of the communities followed by Khagramari and Dhangmari forest area. The mean biomass increments and mean litterfall was 12.8 and $7.91 \mathrm{Mg} \mathrm{ha}^{-1} \mathrm{yr}^{-1}$, respectively for the mangrove community (Table 4). During the study, we observed tree mortality along the study 
area, which was negligibly small, and we simply summed the biomass increment of all the surviving trees and then added litterfall to get the aboveground net primary productivity for each small plot. Mean below ground increment was estimated to be $7.85 \mathrm{Mg} \mathrm{ha}^{-1} \mathrm{yr}^{-1}$. Similarly, belowground production includes the increment of roots of living trees plus turn of fine roots. Most of this turnover is the mortality of fine roots of living trees, the same as the litterfall of aboveground components. But in this study, we were unable to measure the fine root production rather than fine root biomass stock, so our assessment of belowground production did not include fine root turnover.

\section{Discussion}

\section{Vegetative and reproductive phenology}

This study showed that maximum leaf (Fig. 1a) and stipule (Fig. 1b) litterfall of all three species occurred in spring summer and minimum litterfall of leaves and stipules was in winter. Other studies on Indian Sundarbans have recorded similar patterns of leaf and total litterfalls was highest in premonsoon season (March-June; Ghosh and Banerjee 2013) and on Okinawa Island have recorded similar patterns of leaf and stipule litterfalls for K. obovata (Hardiwinoto et al. 1989; Gwada et al. 2000) and B. gymnorrhiza (Hardiwinoto et al. 1989; Kamruzzaman et al. 2013). Similar findings were also observed by Duke (2006), with peak leaf litterfall of $R$. stylosa in the northern hemisphere occurring between April-August, and peak stipule litterfall between May-August. Lee (1989) reported that $K$. obovata in Hong Kong had a bimodal pattern of leaf and stipule litterfall, with peaks in spring (February-June) and late summer (August-November).

While there was no clear seasonal pattern in branch litterfall (Fig. 1c), it was normally low, but was very high in months with typhoons due to strong winds. Similar observations were recorded on Okinawa Island by Kamruzzaman et al. (2013a, 2013b) for K. obovata and B. gymnorrhiza in Manko wetland and Hardiwinoto et al. (1989) for K. obovata and B. gymnorrhiza in Ohura Bay. Mackey and Smail (1995) also reported that branch litterfall of Avicennia marina (Forssk.) Vierh. was correlated with storms on the Brisbane River, Queensland, Australia.Litterfall of flowers of all 
three species was peaked in spring summer (Fig. 2d). The timing of litterfall of mature propagules of B. gymnorrhiza was in July, which was consistent with the findings of Hardiwinoto et al. (1989).

The mean conversion rate of flowers to propagules for B. sexangula (5.3\%) was higher than the 3\% reported for R. stylosa in Darwin Harbour, Australia within the family Rhizophoraceae (Coupland et al. 2006) and the 3.8\% observed in northeastern Australia (Duke et al. 1984). Hogarth (1999) reported the conversion rate of flowers to propagules was 7\% for Rhizophora mangle L. and $13 \%$ for $R$. apiculata BL. The mean conversion rates of flowers to propagules of $B$. sexangula (5.3\%) was similar to the rate reported for B. gymnorrhiza (3.2-4.9\%) in Fiji (Tyagi 2003), but lower than that of B. gymnorrhiza (16.8\%) in northeastern Australia (Duke et al. 1984). According to Primack et al. (1981), the high rates of the conversion rates of flowers to propagules of all three species indicate self-compatibility, as in Sonneratia alba J. Simth. The conversion rates of flowers to propagules in the present study varied from species to species, which may be due to variation in pollinators, nutrients, substrates, or internal conditions of the plants.

The mean total litterfall of $H$. fomes observed in the present study $\left(1015 \mathrm{~g} \mathrm{~m}^{-2}\right.$ year $\left.^{-1}\right)$ was higher than that the litterfall of $R$. stylosa in the South Pacific (777 $\mathrm{g} \mathrm{m}^{-2}$ year ${ }^{-1}$; Woodroffe 1984), and lower than that in Papua New Guinea (1430 $\mathrm{g} \mathrm{m}^{-2}$ year ${ }^{-1}$ Leach and Burgin 1985). The mean total litterfall of B. sexangula (1640 $\mathrm{g} \mathrm{m}^{-2}$ year $\left.^{-1}\right)$ was higher than that recorded in Ohura Bay, Okinawa Island (930 $\mathrm{g} \mathrm{m}^{-2}$ year ${ }^{-1}$; Kamruzzzman et al. 2012). Leaves constituted over $50 \%$ of the total litterfall for all three species, which is similar to the $61.2 \%$ and $61.0 \%$ reported for Rhizophora apiculata and R. mucronata Lamk, respectively (Wafar et al. 1997). The contributions of reproductive organ litterfall to total litterfall observed in the present study (26.4\% for B. sexangula, and $30.7 \%$ for $H$. fomes), were higher than those of other mangrove species such as (R. apiculata 21.8\% and R. mucronata 23.2\%; Wafar et al. 1997). The result was lower than the contributions of reproductive organ to total litterfall $40.0 \%$ for B. gymnorrhiza in the Okinawa Island, japan 
(Kamruzzaman et al. 2012). Our results indicate that litterfall from these mangrove species is a major contributor to the food chains of the surrounding marine and mangrove ecosystems.

\section{Biomass, carbon storage, and carbon sequestration}

This study showed that the mean above-ground biomass (AGB) of $176.0 \mathrm{Mg} \mathrm{ha}^{-1}$ was in the documented range of 40.70 279.03 $\mathrm{Mg} \mathrm{ha}^{-1}$ in the mangrove forests of East Sumatra, Indonesia (Kusmana et al., 1992), or of 123.5 383.5 $\mathrm{Mg} \mathrm{ha}^{-1}$ in the mangrove forests of Dominican Republic (Sherman et al., 2003). The present value of AGB was almost identical to that (159 $\mathrm{Mg} \mathrm{ha}^{-1}$ ) of Rhizophora apiculata dominated mangrove forest in southern Thailand (Christensen, 1978) and (163 $\mathrm{Mg} \mathrm{ha}^{-1}$ ) of B. gymnorrhiza dominated forest along the Okukubi River, Okinawa Island, Japan (Kamruzzaman et al., 2017). This value was higher than those reported for subtropical mixed mangrove forest at Ishigaki Island, southern Japan (78.6 $\mathrm{Mg} \mathrm{ha}^{-1}$; Suzuki and Tagawa, 1983). The present value of accumulation of mean aboveground biomass was within the converted range of AGB from aboveground biomass carbon for Sundarbans mangrove forests $\left(55.3 \sim 153.4 \mathrm{Mg} \mathrm{ha}^{-1} \mathrm{C}\right.$; Chanda et al. 2016). In the present study, mean AGB (176 $\left.\mathrm{Mg} \mathrm{ha}^{-1}\right)$ was also higher than that in Rhizophora mucronata (59.95 $\mathrm{Mg} \mathrm{ha}^{-1}$ ) and Avicennia marina (117.65 $\mathrm{Mg} \mathrm{ha}^{-1}$ ) in the southeast coast of India, both are claimed by (Kathiresen et al., 2013), However, AGB values vary with the mangrove forest: $281 \mathrm{Mg} \mathrm{ha}^{-1}$ in Rhizophora forest (Tamai et al., 1986), $357 \mathrm{Mg} \mathrm{ha}^{-1}$ in Sonneratia forest (Komiyama et al., 1987) and $315 \mathrm{Mg} \mathrm{ha}^{-1}$ in Avicennia germinans (Fromard et al., 1998), 94.8 $\mathrm{Mg} \mathrm{ha}^{-1}$ in a secondary mangrove forest of $R$. mucronata and Bruguiera gymnorrhiza (Suzuki and Tagawa, 1983) and 62.9 $\mathrm{Mg} \mathrm{ha}^{-1}$ in a $R$. mangle forest (Golley et al., 1962).

In the present study, mean belowground biomass (BGB) was $96 \mathrm{Mg}^{-1}$ and $\mathrm{BGB}$ for Avicennia officinalis (53.6 $\mathrm{Mg} \mathrm{ha}^{-1}$ ) which were higher than A. marina (43 $\mathrm{Mg} \mathrm{ha}^{-1}$ ) and in $R$. mucronata (30.7 $\mathrm{Mg} \mathrm{ha}^{-1}$ ) (Kathiresen et al., 2013). The present value is significantly higher than 32.4 $\mathrm{Mg} \mathrm{ha}^{-1}$ in the Sonneratia forest (Komiyama et al., 1987) but marginally higher than $87.5 \mathrm{Mg}$ $\mathrm{ha}^{-1}$ in the Ceriops tagal (Komiyama et al., 2000). However, the mean values are lower than that of 
other mangrove forests: 106-173 $\mathrm{Mg} \mathrm{ha}^{-1}$ for Bruguiera, and 187-273 $\mathrm{Mg} \mathrm{ha}^{-1}$ for Rhizophora (Komiyama et al., 1987).

It is important to mention that AGB of the studied mangrove communities is accounted for mainly due to stem biomass and is also a permanent indicator of biomass increment. Small branches and leaves mainly contributed to litterfall production. Compared to the previous studies, the present study indicates that biomass productivity of the mangrove species in the present study was relatively high among the mangrove forests in the tropical and subtropical areas, showing that mean annual aboveground production of $12.8 \mathrm{Mg} \mathrm{ha}^{-1} \mathrm{yr}^{-1}$ which was higher than the similar observation was made by Putz and Chan (1986), who reported that the average stem production over 31 years for a Rhizophora-Bruguiera forest in Malaysia was $6.7 \mathrm{Mg} \mathrm{ha}^{-1} \mathrm{yr}^{-1}$. The present mean value of AGB increment was also higher than the $5.9 \mathrm{Mg} \mathrm{ha}^{-1} \mathrm{yr}^{-1}$ recorded on $R$. stylosa dominated mangrove forest at Missionary Bay, Hinchinbrook Channel, Australia (Clough, 1998).

In Sundarbans mangrove forest $\left(12.8 \mathrm{Mg} \mathrm{ha}^{-1} \mathrm{yr}^{-1}\right)$ had similar rate of above-ground biomass increment with Bruguiera parviflora stands $\left(13.7 \mathrm{Mg} \mathrm{ha}^{-1} \mathrm{yr}^{-1}\right)$ that was observed by Hossain et al. (2008) and very much higher than A. germinans (0.5 2.61 $\mathrm{Mg} \mathrm{ha}^{-1} \mathrm{yr}^{-1}$ ) in Campeche, Mexico (Day et al., 1996), R. mucronata (2.87 6.2 $\mathrm{Mg} \mathrm{ha}^{-1} \mathrm{yr}^{-1}$ ) in Dutch Bay, Kala Oya and Erumathivu, Sri Lanka (Amarasinghe and Balasubramaniam, 1992) and R. apiculata (6.7 $\mathrm{Mg} \mathrm{ha}^{-1} \mathrm{yr}^{-1}$ ) in Pulau Kecil, Matang Mangrove, Malaysia (Putz and Chan, 1986). The biomass increment rate is highly variable, both locally and regionally and with age for a site (Clough, 1992: Hutchings and Saenger, 1987).

The rate of carbon sequestration recorded in the present study was $14.3 \mathrm{Mg} \mathrm{ha}^{-1} \mathrm{yr}^{-1}$. This value is higher than $13.6 \mathrm{Mg} \mathrm{ha}^{-1} \mathrm{yr}^{-1}$ in a 20-year old stand of Rhizophora apiculata in Peninsular Malaysia (Ong et al., 1995) and 2-fold higher than 7.3 $\mathrm{Mg} \mathrm{ha}^{-1} \mathrm{yr}^{-1}$ in Mahanadi mangrove wetland, India (Aagarwal et al., 2017). This value represents the $\mathrm{CO}_{2}$ equivalent value of $53.35 \mathrm{Mg} \mathrm{ha}^{-1} \mathrm{yr}^{-1}$, which was much higher than 26. $94 \mathrm{Mg} \mathrm{ha}^{-1} \mathrm{yr}^{-1}$ in Mahanadi mangrove wetland, India claimed by 
Aagarwal et al. (2017), which denotes that 1 ha of the mangrove patch in Sundarbans, Bangladesh has the potentiality for accumulating $53.35 \mathrm{Mg}$ carbon from the atmosphere in 1 year.

\section{Conclusion}

This research may significantly contribute to find out the fundamental data for estimating role and impact of Sundarbans forest ecosystems to global carbon cycle and that will provide a path for nature conservation policies in the world. These results may also significantly contribute to finding good strategies and mechanisms to minimize greenhouse gas emissions, developing Sundarbans forest $\mathrm{C}$ conservations and sequestration options. The outcome of this study would be used to the researchers and that will help to gain a consensus about the ecological consideration of Sundarbans ecosystems for build up a sound and safe environment for the next generation people of the world.

\section{Acknowledgements}

The authors are grateful to the Forest Department, Govt. of the People's Republic of Bangladesh for establishing the research plots in the SRF and for assisting the research team in collecting data. The authors are grateful to Mr. Shamim Ahmed for his invaluable assistance during field data collection.

\section{Ethics approval and consent to participate}

Not applicable

\section{Consent for publication}

Not applicable

\section{Funding}

This work was supported by the Grant-in-Aid for Scientific Research from Research Cell, Khulna University, Bangladesh. 


\section{Availability of data and materials}

The datasets used and/or analyzed during the current study are available from the corresponding author on reasonable request.

\section{Author's contributions}

Md. Kamruzzaman developed the concept of the article. Md. Kamruzzaman also established the plots, forest inventory, acquired the data, and data analysis. Sumonta Paul helped in data collection.

Md. Kamruzzaman worked on the manuscript preparation and all authors read and approved the final manuscript.

\section{Competing interests}

The authors declare that they have no competing interests.

\section{References:}

Angsupanich S, Aksornkoae S (1994) Mangrove litter production in Phang-nga Bay, southern Thailand. Tropics 4:35-40

Ashton EC, Hogarth PJ, Ormond R (1999) Breakdown of mangrove leaf litter in a managed mangrove forest in Peninsular Malaysia. Hydrobiologia 413:77-88

Bunt JS (1982) Studies of mangrove litterfall in tropical Australia. In: Clough BF(ed) Mangrove Ecosystems in Australia: Structure, Function and Management. Australian National Univ press, Canberra 193-210

Chave J, Andalo C, Brown S, Cairns MA, Chambers JQ, Eamus D, Fölster H, Fromard F, Higuchi N, Kira T, Lescure JP, Nelson BW, Ogawa H, Puig H, Riéra B, Yamakura T (2005) Tree algometry and improved estimation of carbon density and balance in tropical forests. Oecologia 145:87-99

Chave J, Coomes DA, Jansen S, Lewis SL, Swenson NG, Zanne AE (2009) Towards a worldwide wood economics spectrum. Ecol Let 12:351-366 
Christensen B (1978) Biomass and primary production of Rhizophora apiculata Bl. in a mangrove in Southern Thailand. Aquat Bot 4:43-52

Clarke PJ (1994) Baseline studies of temperate mangrove growth and reproduction; demographic and litterfall measures of leafing and flowering. Aust J Bot 42:37-48

Coupland GT, Paling EI, McGuinness KA (2005) Vegetative and reproductive phenologies of four mangrove species from northern Australia. Aust J Bot 53:109-117

Deshar R, Sharma S, Mouctar K, Wu M, Hoque ATMR, Hagihara A (2012) Self-thinning exponents for partial organs in overcrowded mangrove Bruguiera gymnorrhiza stands on Okinawa Island, Japan. Forest Ecol Manag 278:146-154

Duke NC (1990) Phenological trends with latitude in the mangrove tree Avicennia marina. J Ecol 78:113-133

Gifford RM (2000) Carbon contents of above-ground tissues of forest and woodland trees. National carbon accounting system technical report no. 22. Australian Greenhouse Office, Canbera. p 17

Ghosh R Banerjee K (2013) Inter-relationship between Physio-chemical varaibles and litter production in mangroves of Indian Sundarbans. Marine Science. S11.

Hossain M, Siddique MRH, Saha S, Abdullah SMR (2015) Allometric models for biomass, nutrients and carbon stock in Excoecaria agallocha of the Sundarbans, Bangladesh. Wetlands Ecol Manage 23:765-7774

Iftekhar MS, Saenger P (2008) Vegetation dynamics in the Bangladesh Sundarbans mangroves: a review of forest inventories. Wetlands Ecol Manage 16: 291-312

Kamruzzaman M, Sharma S, Hoque ATMR, Hagihara A (2012) Litterfall of three subtropical mangrove species in the family Rhizophoraceae. J Oceanogr 68: 841-850 
Komiyama A, Havanond S, Srisawatt W, Mochida Y, Fujimoto K, Ohnishi T, Ishihara S, Miyagi

T (2000) Top/root biomass of a secondary mangrove (Ceriops tagal (Perr.) C.B. Rob.) forest. Forest Ecol Manag 139:127-134

Komiyama A, Poungparn S, Kato S (2005) Common allometric equations for estimating the tree weight of mangroves. J Trop Ecol 21:471-477

Leach GJ, Burgin S (1985) Litter production and seasonality of mangroves in Papua New Guinea. Aquat Bot 23:215-224

Mackey AP, Smail G (1995) Spatial and temporal variation in litterfall of Avicennia marina (Forssk.) Vierh. In the Brisbane River, Queensland, Australia. Aquat Bot 52:133-142

Mehlig U (2006) Phenology of the red mangrove, Rhizophora mangle L., in the Caeté Estuary, Pará, equatorial Brazil. Aquat Bot 84:158-164

Rahman MM, Khan MNI, Hoque AKF, Ahmed I (2015) Carbon stock in the Sundarbans mangrove forest: spatial variations in vegetation types and salinity zones. Wetlands Ecol Manage 23: 269-283

Saintilan N (1997) Above- and below-ground biomasses of two species of mangrove on the Hawkesbury River estuary, New South Wales. Mar Freshwater Res 48:147-152

Saito K, Okuno T, Asai A et al (2003) Lectures on modern statistics. Practical Business Education Institute, Tokyo (in Japanese)

Tamai S, Nakasuga T, Tabuchi R, Ogino K (1986) Standing biomass of mangrove forests in southern Thailand. J Jpn Fo Soc 68:384-388

Waring RH, Running SW (1998) Forest ecosystems: analysis at multiple scales. Academic Press, San Diego, California 
Table 1 Kendall's coefficient of concordance W showing the degree of similarity in the monthly changes for the litterfall components of Bruguiera sexangula, Heritiera fomes, and Xylocarpus mekongensis among the years during the study period

\begin{tabular}{llll}
\hline Litterfall component & $\begin{array}{l}\text { Bruguiera } \\
\text { sexangula }\end{array}$ & $\begin{array}{l}\text { Heritiera } \\
\text { fomes }\end{array}$ & Xylocarpus mekongensis \\
\hline Leaf & $0.75^{* *}$ & 0.52 & $0.83^{* * *}$ \\
Stipule & $0.60^{*}$ & $0.64^{*}$ & $0.78^{* *}$ \\
Branch & 0.57 & 0.46 & $0.63^{*}$ \\
Sum of Vegetative organs & $0.75^{* *}$ & $0.78^{* *}$ & $0.87^{* * *}$ \\
Flower bud & $0.69^{*}$ & - & - \\
Flower & 0.55 & 0.52 & 0.48 \\
Immature Fruit & - & 0.58 & 0.12 \\
Propgaule / mature fruit & $0.75^{* *}$ & $0.59^{*}$ & 0.06 \\
Sum of reproductive organs & $0.83^{* * *}$ & $0.84^{* * *}$ & 0.34 \\
Total & $0.86^{* * *}$ & $0.87^{* * *}$ & $0.82^{* * * *}$ \\
\hline
\end{tabular}

*** Significance level $<0.1 \%$; ** Significance level $<1 \%$; $*$ Significance level $<5 \%$

Table 2. Mean number of flowers and propagules / mature fruits $\left(\mathrm{m}^{-2}\right.$ year $\left.^{-1}\right)$ of the three species during the study period

\begin{tabular}{llll}
\hline Reproductive organ & $\begin{array}{l}\text { Bruguiera } \\
\text { sexangula }\end{array}$ & $\begin{array}{l}\text { Heritiera } \\
\text { fomes }\end{array}$ & Xylocarpus mekongensis \\
\hline Flower & $212.5 \pm 5.4^{\mathrm{a}}$ & $357.7 \pm 11.2^{\mathrm{b}}$ & $238.9 \pm 10.3^{\mathrm{a}}$ \\
Propagule / mature fruit & $8.5 \pm 1.1^{\mathrm{a}}$ & $28.9 \pm 1.1^{\mathrm{b}}$ & $13.3 \pm 0.6^{\mathrm{a}}$ \\
\hline
\end{tabular}

Within an organ, with the same letter were not significantly different at a 5\% level of significance using Bonferroni's multiple comparison

Table 3. Mean annual mass ( $\mathrm{g} \mathrm{m}-2$ year-1 $\pm \mathrm{SE}$ ) of litterfall components of the three species during the study period

\begin{tabular}{llll}
\hline Litterfall component & Bruguiera sexangula & Heritiera fomes & $\begin{array}{l}\text { Xylocarpus } \\
\text { mekongensis }\end{array}$ \\
\hline Leaf & $866.9 \pm 124.8(52.9)^{\mathrm{a}}$ & $533.6 \pm 81.6(52.6)^{\mathrm{a}}$ & $681.9 \pm 119.3(65.1)^{\mathrm{a}}$ \\
Stipule & $210.8 \pm 27.5(12.9)^{\mathrm{a}}$ & $79.7 \pm 19.5(7.9)^{\mathrm{b}}$ & $84.4 \pm 22.4(8.1)^{\mathrm{b}, \mathrm{c}}$ \\
Branch & $129.7 \pm 51.4(7.9)^{\mathrm{a}}$ & $89.7 \pm 45.6(8.8)^{\mathrm{a}}$ & $95.2 \pm 27.9(9.1)^{\mathrm{a}}$ \\
Sum of vegetative organs & $1207.5 \pm 203.7(73.6)^{\mathrm{a}}$ & $703.0 \pm 146.7(69.3)^{\mathrm{a}}$ & $861.6 \pm 169.5(82.3)^{\mathrm{a}}$ \\
Flower bud & $66.6 \pm 34.6(4.1)$ & - & - \\
Flower & $147.1 \pm 61.5(9.0)^{\mathrm{a}}$ & $106.9 \pm 16.9(10.5)^{\mathrm{a}}$ & $109.6 \pm 28.6(10.5)^{\mathrm{a}}$ \\
Immature fruit & - & $62.8 \pm 27.5(6.2)$ & $30.3 \pm 5.3(2.9)$ \\
Propagule/mature fruit & $219.0 \pm 106.9(13.4)^{\mathrm{a}}$ & $141.9 \pm 51.9(14.0)^{\mathrm{a}}$ & $45.8 \pm 5.8(4.4)^{\mathrm{b}}$ \\
Sum of reproductive organs & $432.7 \pm 203.1(26.4)^{\mathrm{a}}$ & $311.6 \pm 96.5(30.7)^{\mathrm{b}}$ & $185.7 \pm 59.7(17.7)^{\mathrm{b}, \mathrm{c}}$ \\
Total & $1640.2 \pm 406.8^{\mathrm{a}}$ & $1014.6 \pm 243.2^{\mathrm{b}}$ & $1047.3 \pm 229.2^{\mathrm{b}}$ \\
\hline
\end{tabular}


Table 4: Species wise contribution of biomass and carbon carbon in the study area of Sundarbans.

\begin{tabular}{ccccccc}
\hline $\begin{array}{c}\text { Component } \\
\left(\mathrm{Mg} \mathrm{ha}^{-1}\right)\end{array}$ & A. cuculata & A. officinalis & B. sexangula & E. agallocha & H. fomes & X. Mecongensis \\
\hline AGB & $0.9 \pm 0.08$ & $109.4 \pm 3.4$ & $47.3 \pm 1.1$ & $11.7 \pm 0.3$ & $47.4 \pm 2.1$ & $26.4 \pm 1.1$ \\
BGB & $0.6 \pm 0.1$ & $53.96 \pm 2$ & $26.8 \pm 0.8$ & $8.1 \pm 0.2$ & $27.6 \pm 0.9$ & $14.9 \pm 0.4$ \\
TB & $1.6 \pm 0.1$ & $163.5 \pm 5.4$ & $74.2 \pm 1.9$ & $19.9 \pm 0.5$ & $75.1 \pm 3.1$ & $41.5 \pm 1.5$ \\
AGC & $0.4 \pm 0.04$ & $50.9 \pm 1.7$ & $22.3 \pm 0.5$ & $5.6 \pm 0.3$ & $22.3 \pm 0.9$ & $12.2 \pm 0.4$ \\
BGC & $0.32 \pm 0.03$ & $25 \pm 1.1$ & $12.8 \pm 0.4$ & $3.8 \pm 0.1$ & $12.9 \pm 0.4$ & $6.9 \pm 0.3$ \\
TBC & $0.7 \pm 0.1$ & $75.9 \pm 2.4$ & $35.1 \pm 0.9$ & $9.4 \pm 0.4$ & $35.2 \pm 1.2$ & $19.1 \pm 0.7$ \\
\hline
\end{tabular}



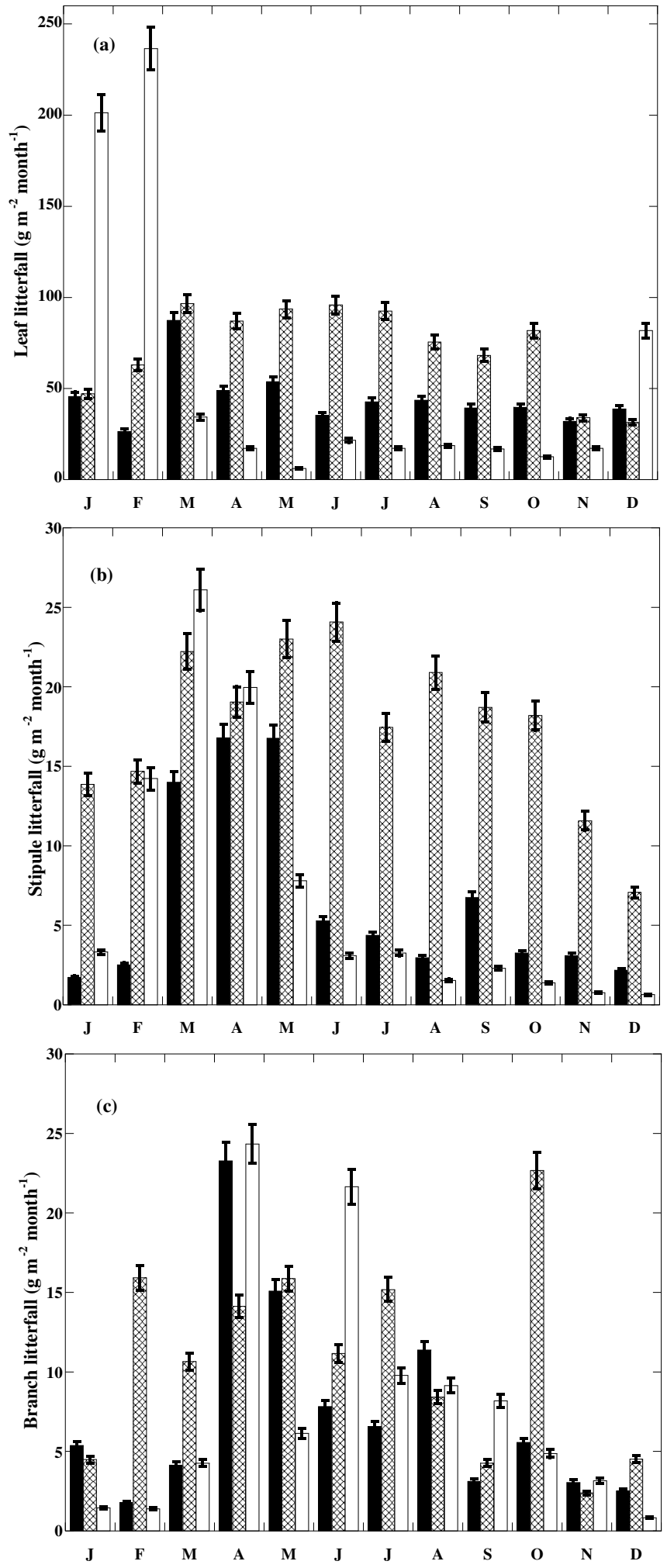

Fig. 1: Monthly patterns of litterfall of vegetative organs litterfall of $B$. sexangula (hatched columns), H. fomes (filled columns), and X. mekongensis (open cloumns). Vertical bars represent the standard error of the mean. 

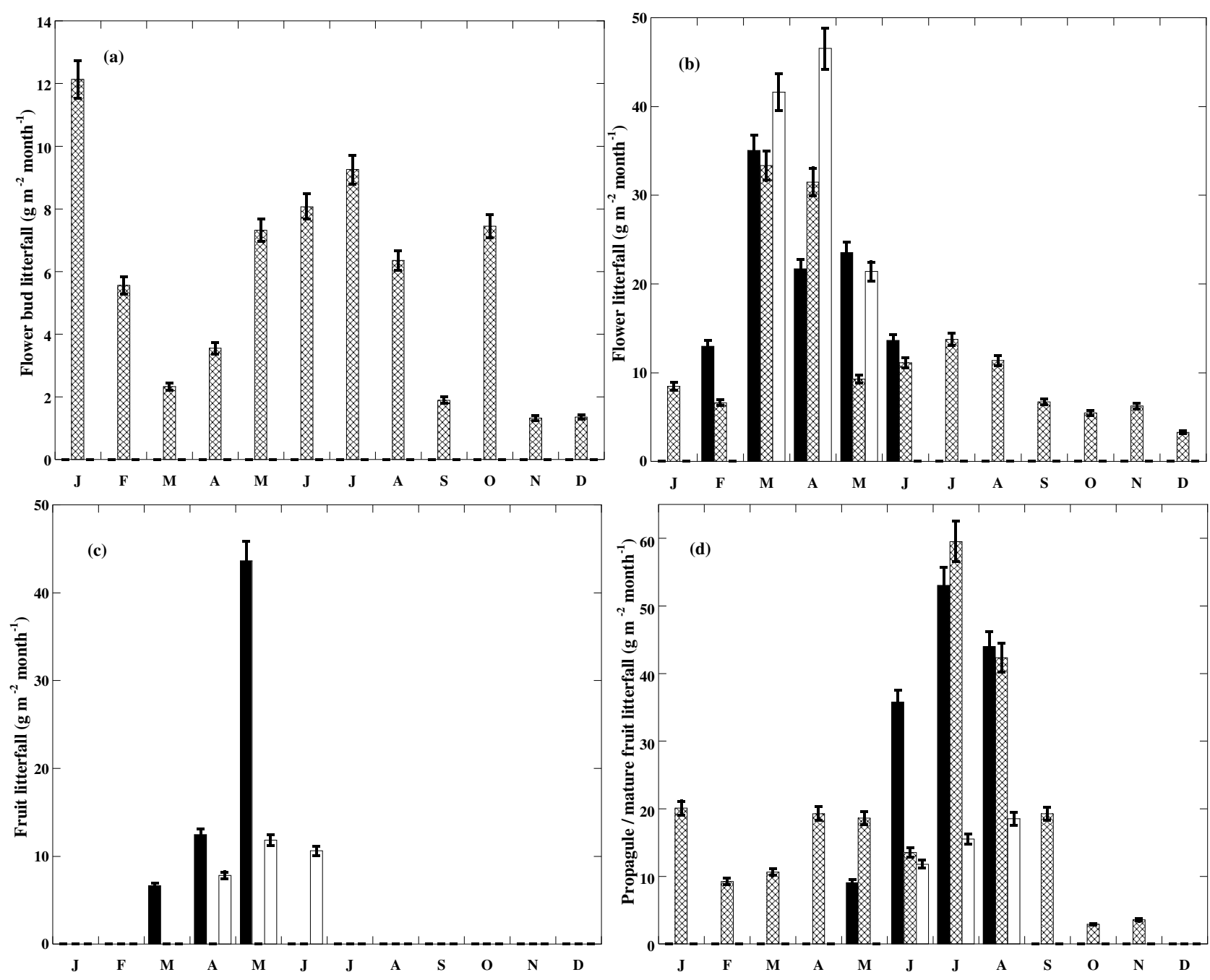

Fig. 2: Monthly patterns of litterfall of reproductive organs litterfall of B. sexangula (hatched columns), H. fomes (filled columns), and X. mekongensis (open cloumns). Vertical bars represent the standard error of the mean. 


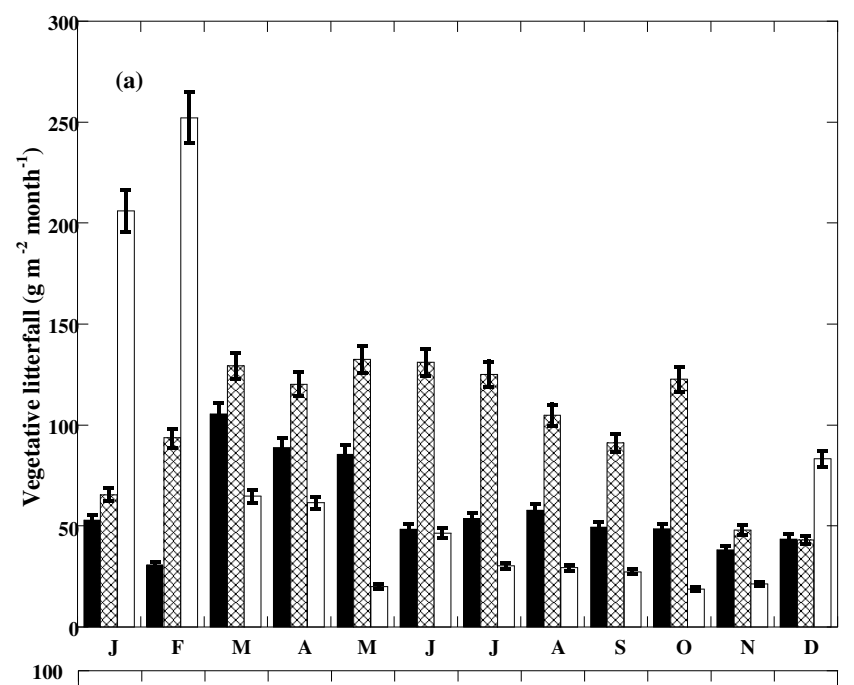

(b)
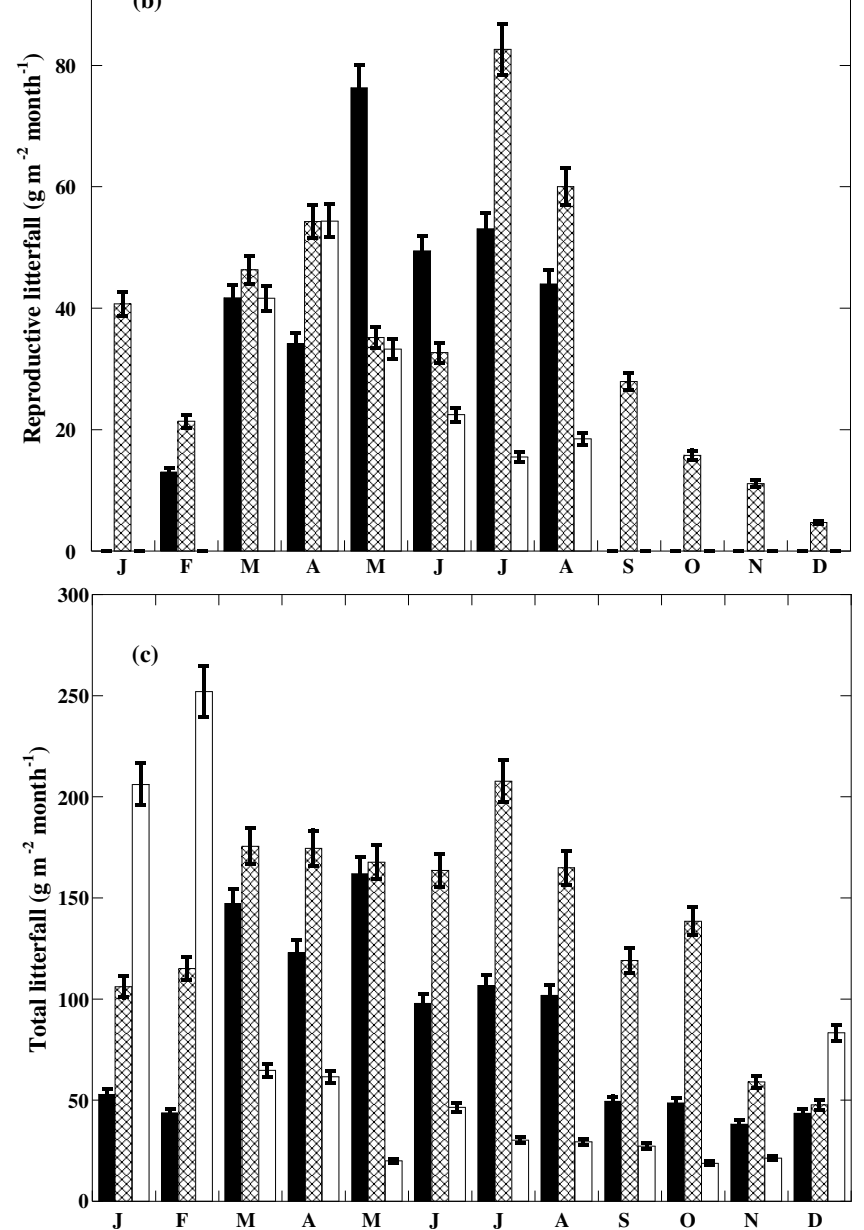

Fig.3: Monthly patterns of litterfall of Vegetative and reproductive organs, and total litterfall of B. sexangula (hatched columns), H. fomes (filled columns), and X. mekongensis (open cloumns). Vertical bars represent the standard error of the mean. 

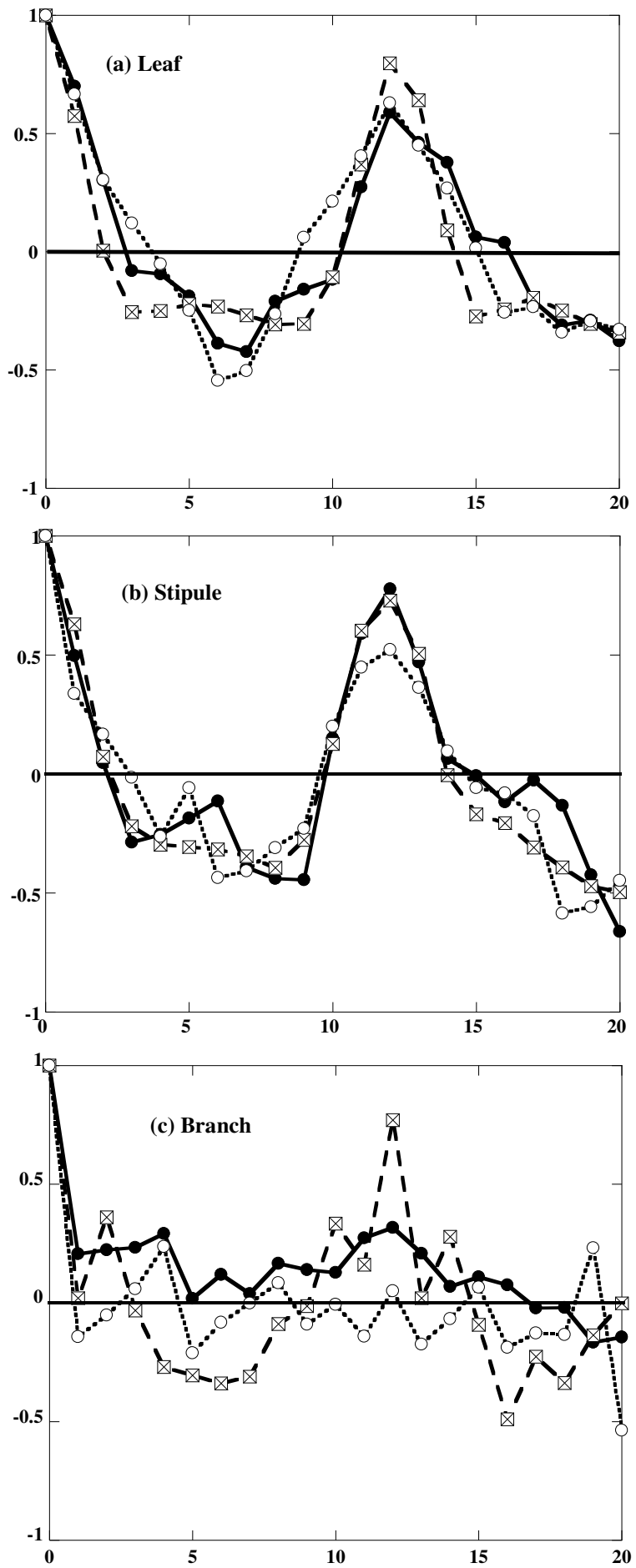

Fig. 4: Correlograms of monthly vegetative litterfall components of B. sexangula (open circles), $H$. fomes (filled circles), and X. mekongensis (hatched square). 

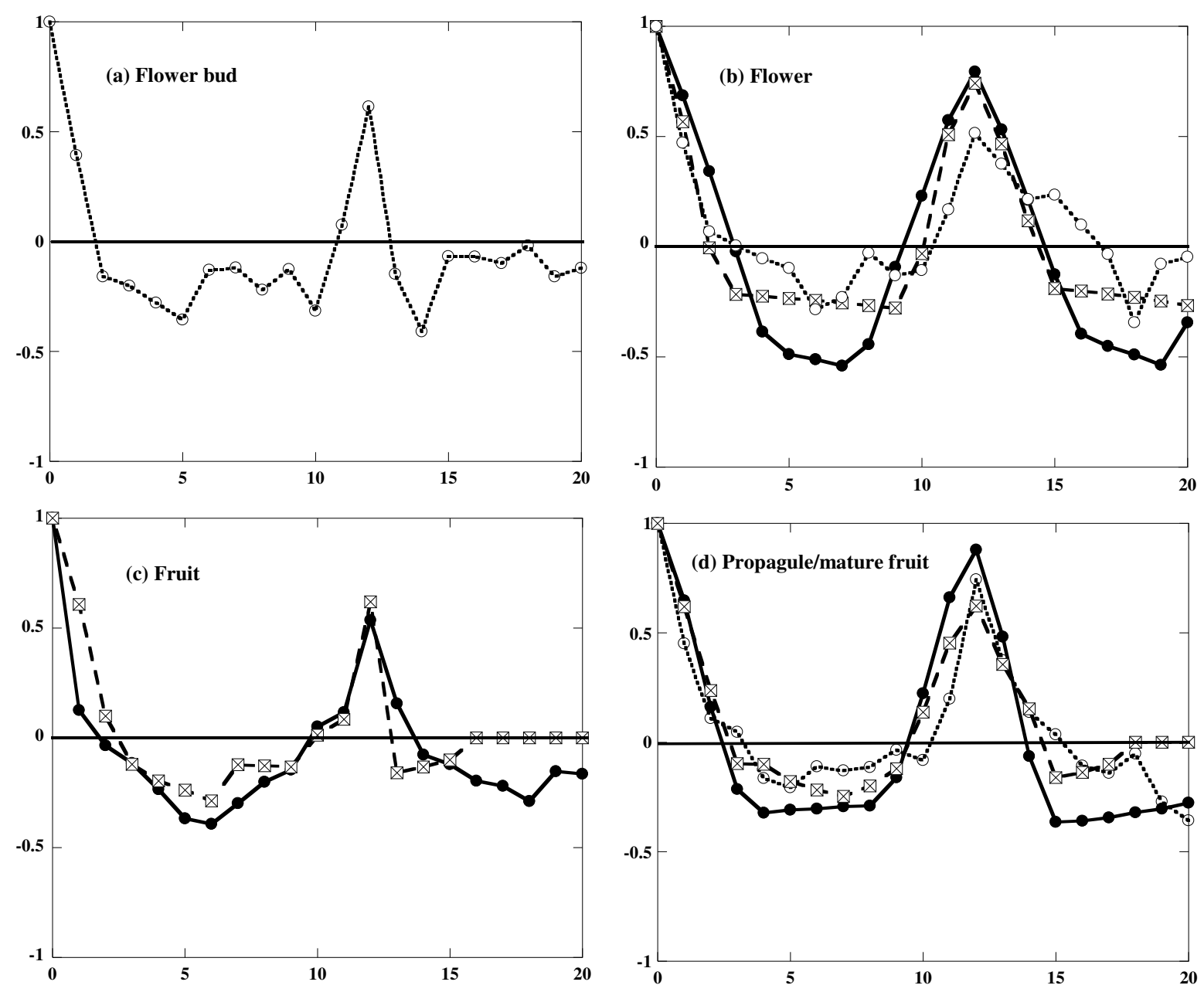

Fig. 5: Correlograms of monthly reproductive litterfall components of B. sexangula (open circles), $H$. fomes (filled circles), and $X$. mekongensis (hatched square). 


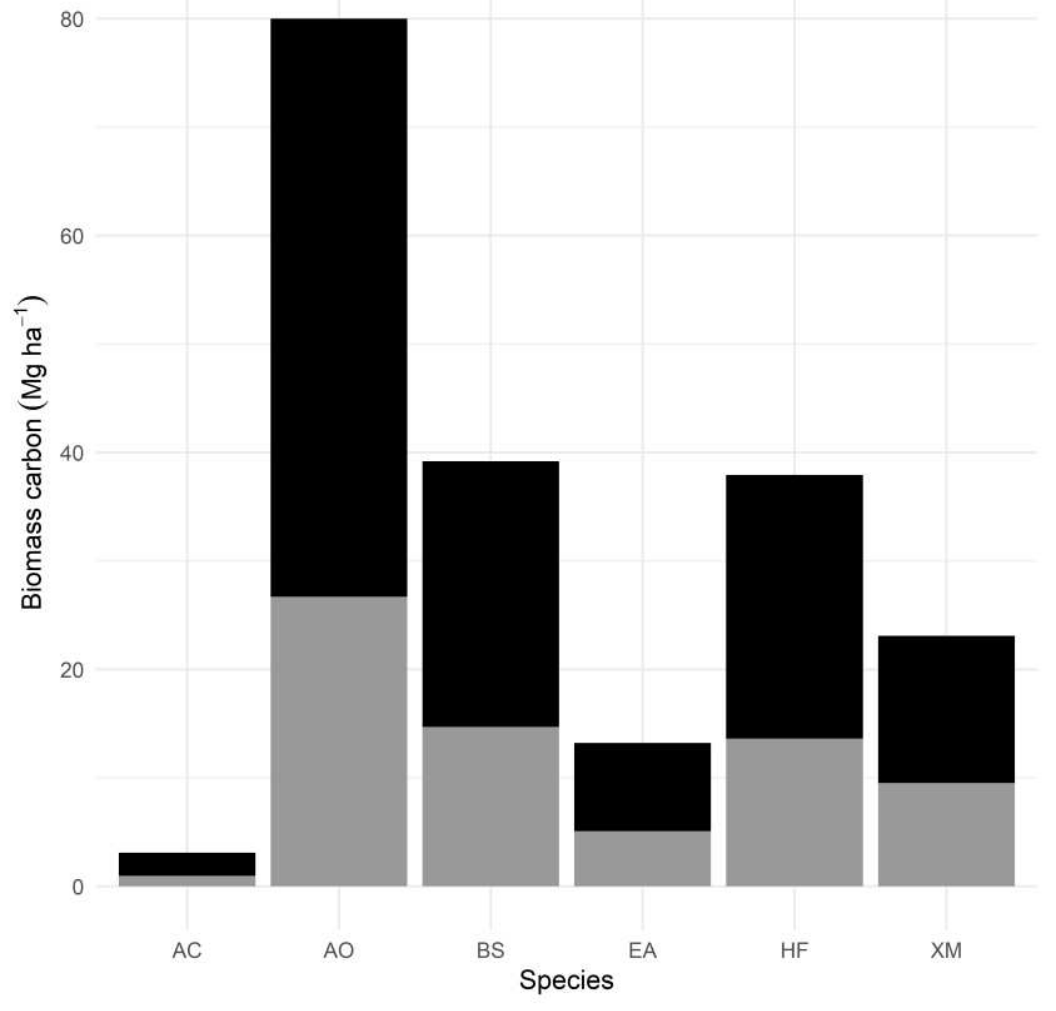

Fig. 6: Species wise contribution to biomass carbon stocks per hectare in the study area . ( $\boldsymbol{\square}$ : above ground biomass carbon; $\square$ : below ground biomass carbon).

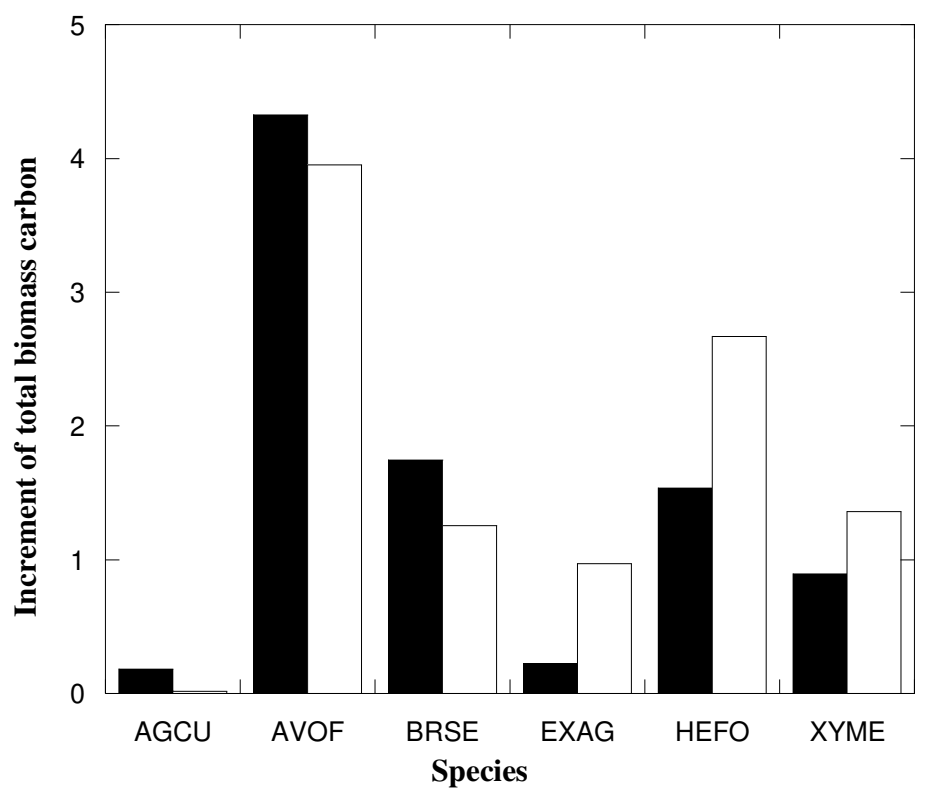

Fig. 7 : Species wise contribution to biomass carbon sequestration rate in the study area increment of total biomass carbon. Dark column: $1^{\text {st }}$ year increment (2018-2019); open column: $2^{\text {nd }}$ year increment (2019-2020). AGCU-Agalia cucullata; AVOF-Avicennia officinalis; BRSE-Bruguiera sexangula; EXAG-Excoecaria agallocha; HEFO- Heritiera fomes; XYME-Xylocarpus mekongensis. 
Figures
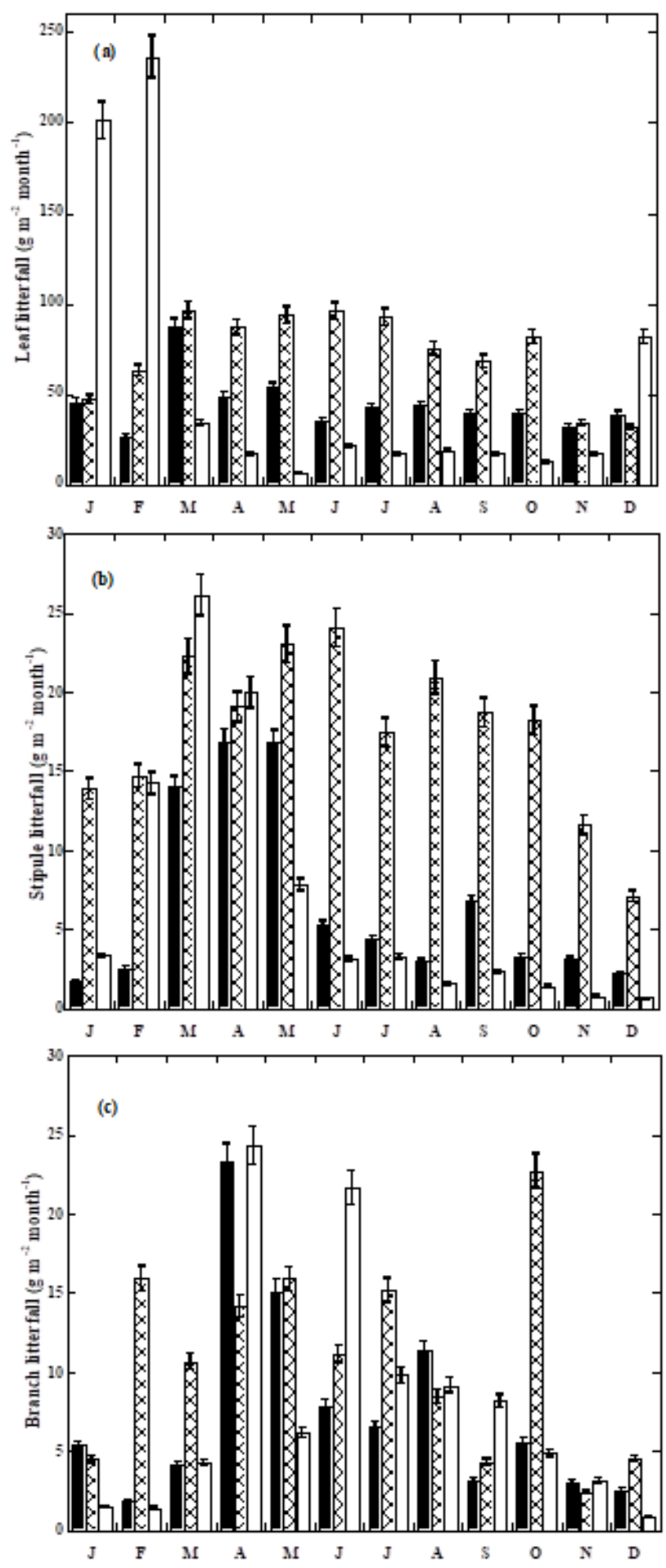

Figure 1

Monthly patterns of litterfall of vegetative organs litterfall of B. sexangula (hatched columns), $\mathrm{H}$. fomes (filled columns), and X. mekongensis (open cloumns). Vertical bars represent the standard error of the mean. 

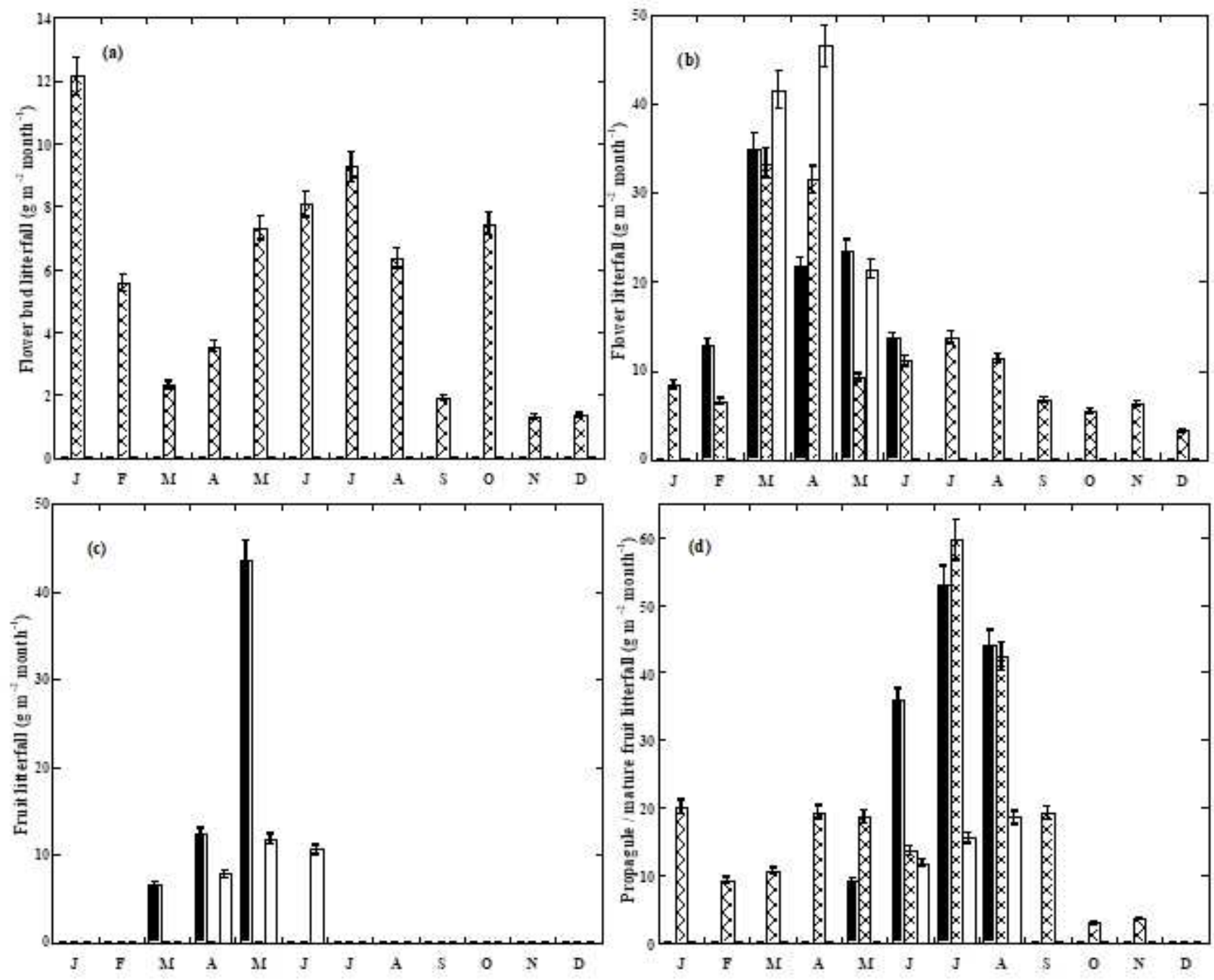

Figure 2

Monthly patterns of litterfall of reproductive organs litterfall of B. sexangula (hatched columns), H. fomes (filled columns), and X. mekongensis (open cloumns). Vertical bars represent the standard error of the mean. 

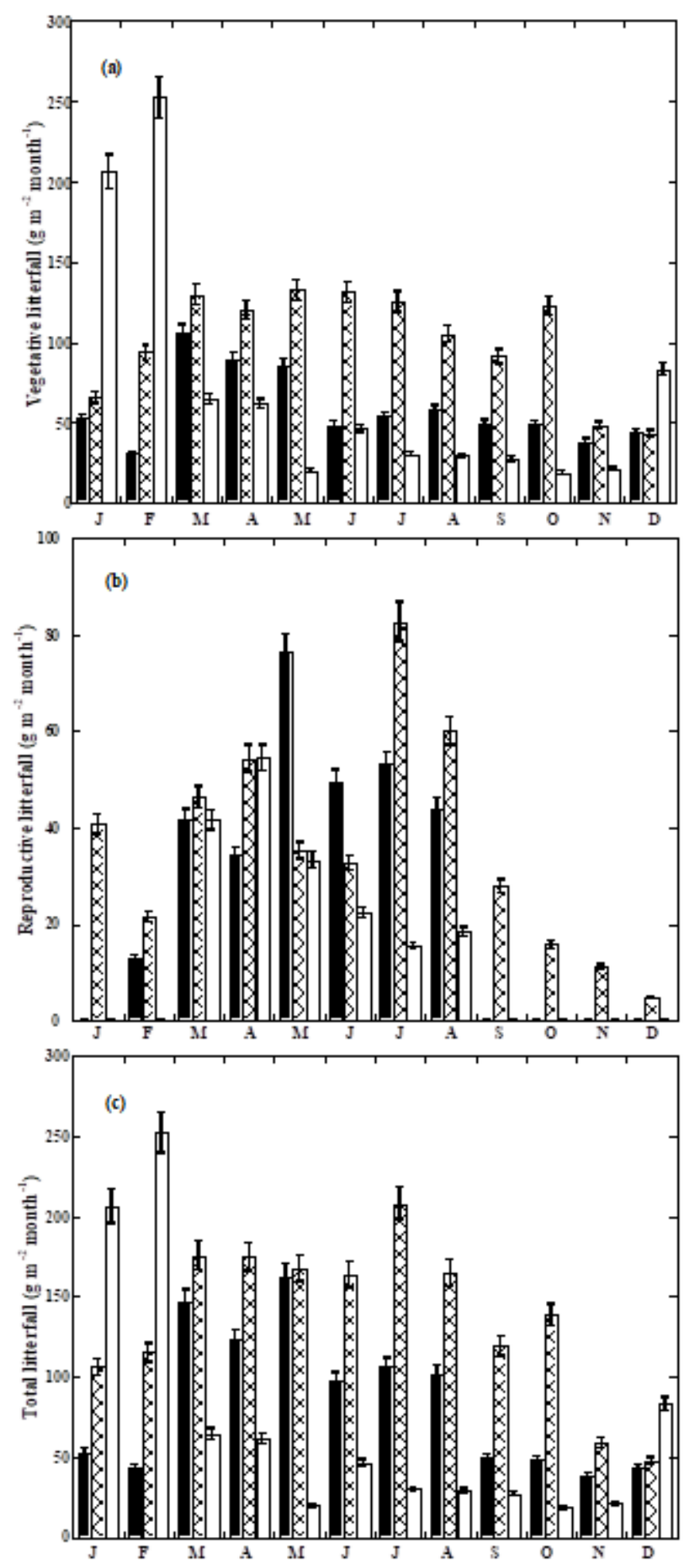

Figure 3

Monthly patterns of litterfall of Vegetative and reproductive organs, and total litterfall of B. sexangula (hatched columns), H. fomes (filled columns), and X. mekongensis (open cloumns). Vertical bars represent the standard error of the mean. 

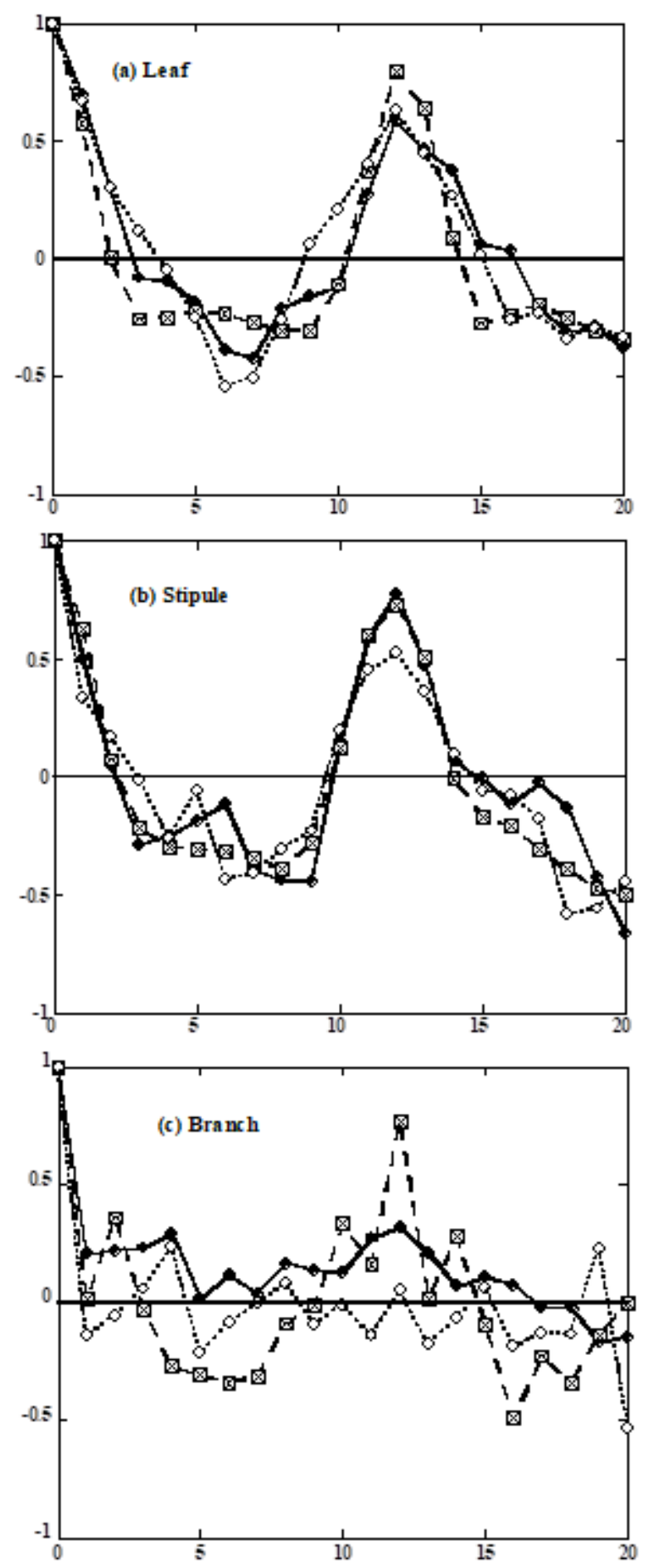

\section{Figure 4}

Correlograms of monthly vegetative litterfall components of B. sexangula (open circles), H. fomes (filled circles), and X. mekongensis (hatched square). 

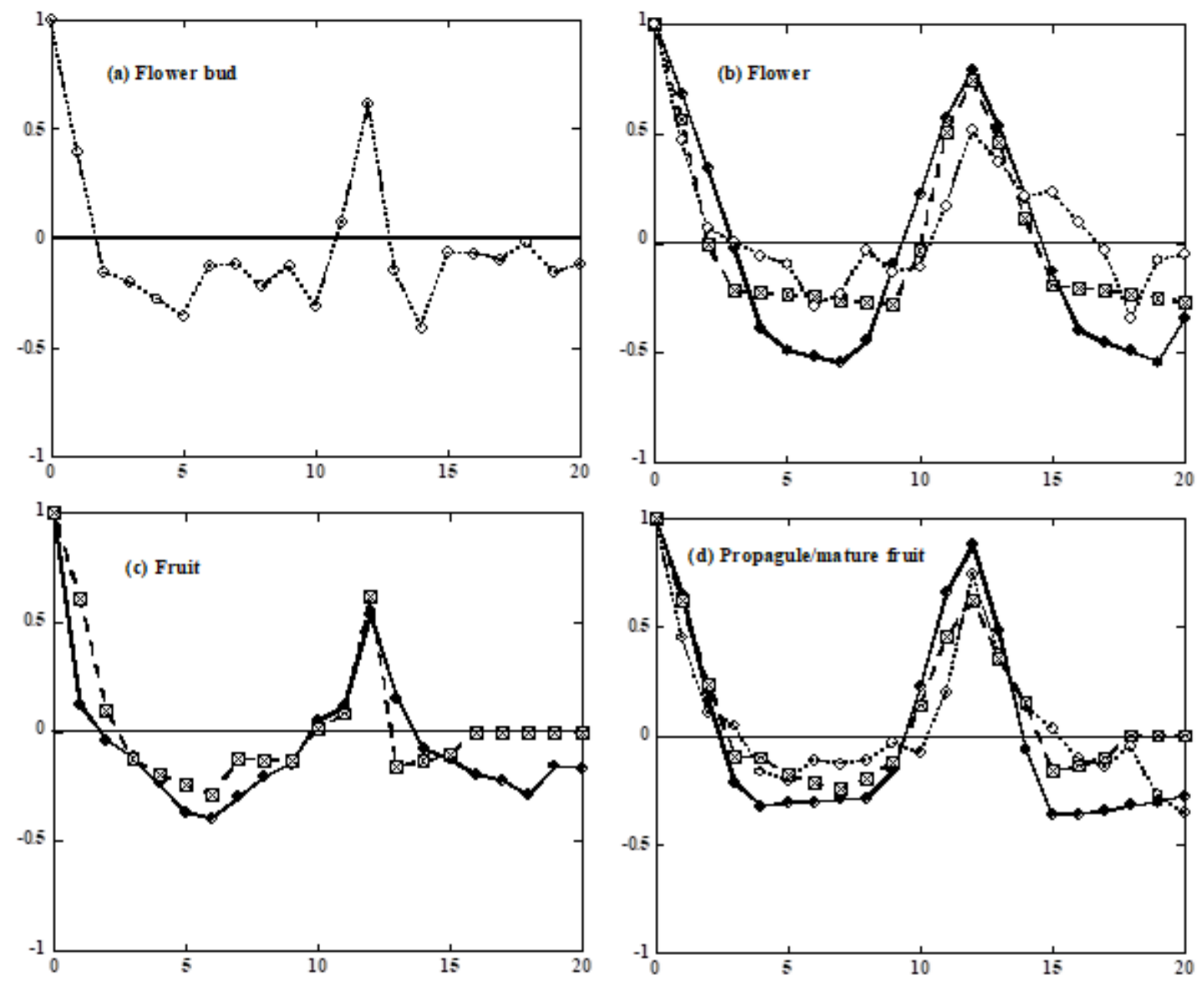

\section{Figure 5}

Correlograms of monthly reproductive litterfall components of B. sexangula (open circles), H. fomes (filled circles), and X. mekongensis (hatched square). 


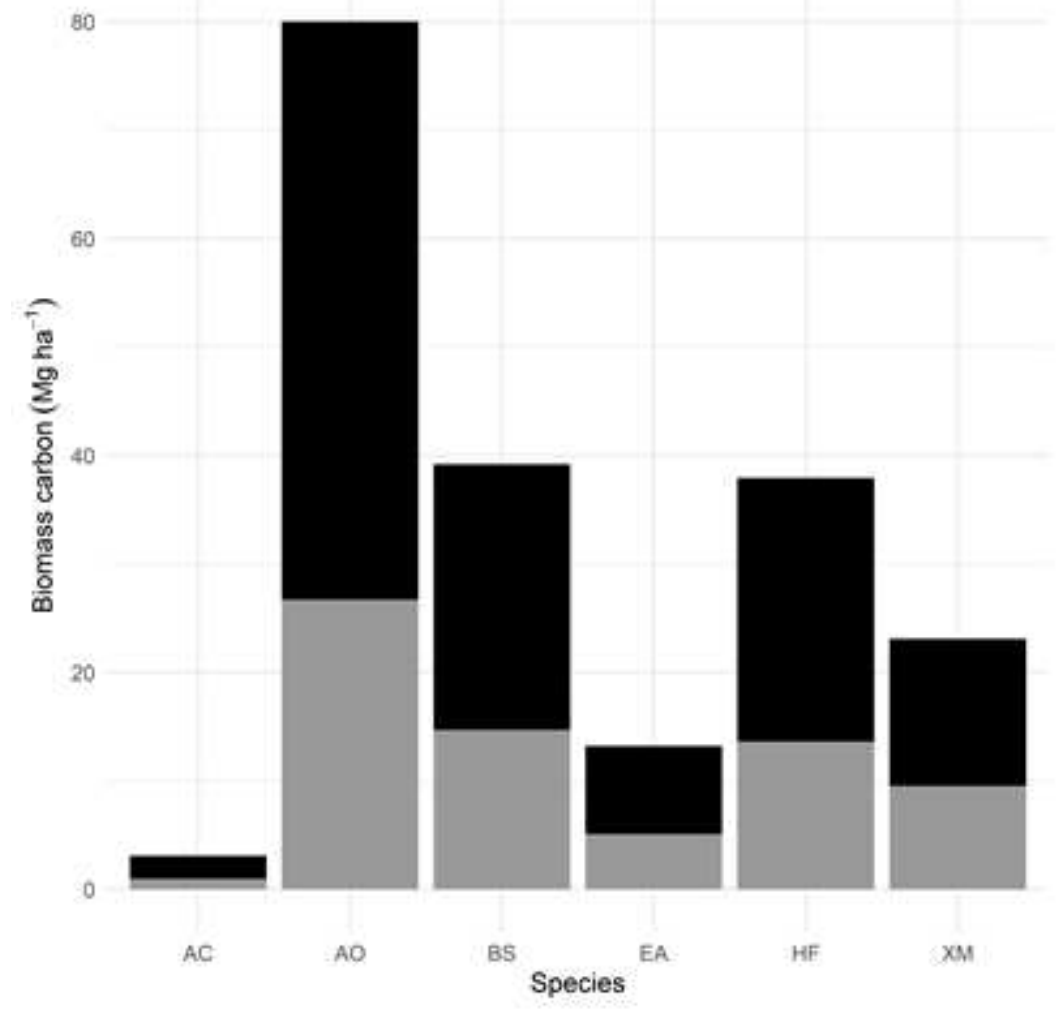

Figure 6

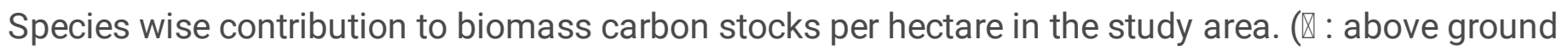
biomass carbon; $\varangle$ : below ground biomass carbon).

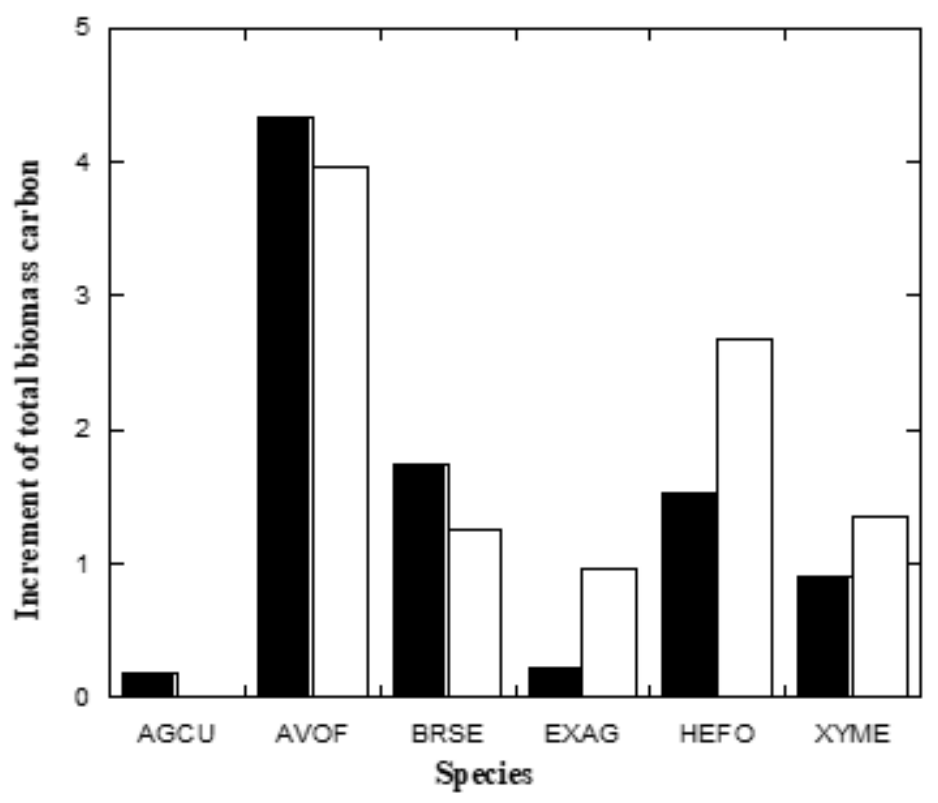

Figure 7 
Species wise contribution to biomass carbon sequestration rate in the study area increment of total biomass carbon. Dark column: 1st year increment (2018-2019); open column: 2nd year increment (20192020). AGCU-Agalia cucullata; AVOF-Avicennia officinalis; BRSE-Bruguiera sexangula; EXAG-Excoecaria agallocha; HEFO- Heritiera fomes; XYME-Xylocarpus mekongensis. 